\title{
Effects of fertilization and cutting on the chemical composition of vegetation and soils of mountain heathlands in Spain
}

\author{
Marcos, E.*; Calvo, L. \& Luis-Calabuig, E. \\ Area of Ecology, Faculty of Biology, University of León, 24071 León, Spain; \\ *Corresponding author; Fax+34987291501; E-mail deglcg@unileon.es
}

\begin{abstract}
In the mountains of northern Spain, patches dominated by Calluna vulgaris are scarce and they may disappear or change as a result of continued lack of management and possibly increasing nutrient availability through atmospheric deposition. The effects in the soil properties and in the composition of Calluna vulgaris and Erica tetralix shoots on heathlands dominated by Calluna and Erica subjected to fertilization and experimental cutting were studied in three mountain passes in northern Spain. A total of $901-\mathrm{m}^{2}$ plots received different combinations of cutting and twice the estimated atmospheric deposition of nitrogen $\left(5.6 \mathrm{~g} . \mathrm{m}^{-2} \cdot \mathrm{yr}^{-1}\right)$ as ammonium nitrate. One of the dominant ericaceous species (Calluna and Erica) was selectively cut by hand at ground level and their nitrogen shoot content were compared in the presence or absence of the other. Treatments were carried out in April 1998. In each plot one soil sample was taken in the original situation and 12, 24 and 36 months after the treatments. Soil properties such as organic matter, total nitrogen, available phosphorus and $\mathrm{pH}$ were determined. In every plot five shoots of Calluna and Erica were also taken to analyse total nitrogen content in the original situation and 12,24 and 36 mo after the treatments.

Nitrogen addition does not necessarily lead to increased levels in the soil, and a clear pattern was not found in the three areas. A gradual decrease in available phosphorus content was detected in the three areas until two years after treatment, although values tend to recover in two of the areas in the third study year. An increase in organic matter content was observed in all areas. It is concluded that increased nutrients alone, at twice the rate of the estimated current atmospheric deposition for the area, which is relatively low, will not alter significantly the soil characteristics of the mountain heathland stands. A clear increase in plant N-content is observed in the fertilized plots in comparison with the non-fertilized ones and Calluna always has higher nitrogen content than Erica. This increase is most pronounced one year after the treatments started in one of the areas and after two years in the other two areas. In some cases the elimination of one species is seen to favour nitrogen increase in the other.
\end{abstract}

Keywords: Calluna vulgaris; Erica tetralix; Fertilizer; Soil change.

\section{Introduction}

Heathlands dominated by Calluna vulgaris have been maintained in W and NW Europe as a result of grazing by domestic animals and cutting for peat and fuel (e.g. Webb 1998). However, in the last few decades traditional management has disappeared in many places and heathlands is invaded by scrub, Pteridium aquilinum or other vegetation of less ecological value. Heathlands were recognized as an important habitat by the European Union Habitats Directive in 1986 and projects have been started at national and international levels aiming at preserving and restoring existing heathlands and re-creating them within the original distribution area.

This study was carried out in the Cantabrian Mountains, Spain, where heathlands dominated by Calluna vulgaris still occur. Historically a great part of the pastures and associated vegetation in the mountains of $\mathrm{N}$ Spain was used as summer grazing by transhuman flocks of merino sheep. Heathlands were regularly cut and burnt to establish pastures (Calvo et al. 2002; Fernández 2002). This type of management has changed in the last decades: agricultural policies have favoured the reduction in the number of sheep and the increase of cattle and horses based on subsidies (Fernández 2002). The feeding patterns of these grazers are different from those of sheep (Lake et al. 2001). Nowadays, patches characterized by Calluna vulgaris and other dwarf ericaceous such as Erica tetralix are scarce; in many places their extent is less than $20 \%$ of the historical area (Farrell 1993). They may disappear or deteriorate as a result of further lack of management and possibly increasing nutrient availability through atmospheric deposition.

In the last few decades there has been increased deposition of atmospheric pollutants such as $\mathrm{NO}_{2}$ throughout Europe, with levels between 200-400 mol.ha ${ }^{-1} \cdot \mathrm{yr}^{-1}$ detected in Spain by 1988 (van Jaarsveld \& Onderlinden 1990). Recent studies in NW Europe, records of nitrogen atmospheric deposition in mountain areas in Spain suggest an increase in the availability of this nutrient to the vegetation (Rivero Fernández et al. 1996). There is ample evidence in the literature of the negative effects of increasing nitrogen deposition on heathland ecosystems 
(Heil \& Diemont 1983; Aerts et al. 1990; Aerts \& Heil 1993; Bobbink \& Heil 1993; Power et al. 1995; Bobbink et al. 1998; Power et al. 1998).

Generally, heathlands occur on nutrient-poor acidic soils, that are particularly phosphorus-limited (Groves 1981; Gimingham 1972); any increase in soil resources is likely to lead to changes in soil characteristics. The Cantabrian mountain range where Calluna heathlands occur are characterized by strongly podzolized soils with few nutrients, $\mathrm{P}$ being the most limiting element (Fernández 2002). As a result of increased N-deposition, changes are thought to occur in these nutrient-poor soils. Furthermore, the capacity or ability of the most representative species present in the area to capture nutrients probably influences chemical soil properties. Large increase in above-ground growth and litter production in response to N-treatment has been found by Power et al. (1998). Changes in microbial processes, decomposition rate and $\mathrm{N}$-mineralization was shown by Singh (1995) and Lee \& Caporn (1998). The foliar Ncontent of some species has been shown to increase with atmospheric input of $\mathrm{N}$ (Pitcairn et al. 1998). The main interest of this work is that no previous studies have been carried out in the mountain heathlands of the Iberian Peninsula. The conclusions obtained could be useful for vegetation decision makers in protected areas. The objectives of this study were to determine the effects of increased nitrogen availability on the chemical properties of the soil and on the chemical composition of Calluna vulgaris and Erica tetralix shoots. A second aim was to analyse the $\mathrm{N}$-content in the shoots of one of the dominant shrub species (Calluna vulgaris and Erica tetralix) when the other is removed by cutting.

\section{Material and Methods}

Three mountain passes, 'puertos', ca. $25 \mathrm{~km}$ apart from each other, were selected in the province of León

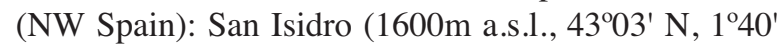
W), Las Señales (1625 m a.s.1., 430.'40" N, $1^{\circ} 33^{\prime} \mathrm{W}$ )

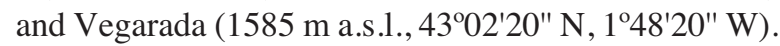
The area has a Eurosiberian climate (Rivas Martínez et al. 1987), characterized by the absence of a dry period in the summer, or a dry period of less than two months. Mean annual precipitation is $1320 \mathrm{~mm}$ and mean annual temperature is $5.5{ }^{\circ} \mathrm{C}$. The passes offer a range of different soil characteristics, mainly in terms of soil moisture - Las Señales being the wettest and San Isidro the driest area - and organic matter, $\mathrm{N}$ and P. Soils in all areas are podzols on different bedrock.

In each pass a site of $1 \mathrm{~km}^{2}$ containing a significant proportion of both Calluna and Erica was selected. There are no records of when they were burn or cut the last time, but all stands seem to be in a mature stage (sensu Watt 1955). Six 1- $\mathrm{m}^{2}$ plots were established in April 1998 in each area. Vegetation structure and soil nutrient levels were altered as follows. 1. In two plots Calluna was cut by hand at ground level (C). 2. In two others Erica was cut likewise (E). The cutting treatment was applied at the start of experiment and the material was removed. 3. Two plots were not cut. One of each of the two-paired plots received an application of $\mathrm{N}$-fertilizer (as ammonium nitrate) within two weeks after snow melting each year (late April, early May) from 1998 until 2001. The fertilizer level, $5.6 \mathrm{~g} \cdot \mathrm{m}^{-2} \cdot \mathrm{yr}^{-1}$, was chosen to be twice the estimated current background pollution level in the area (Rivero Fernández et al. 1996). Five replicates were established in each area. Thus 30 plots were established in each area. Fig. 1 shows the layout of the experiments.

Initial measurements were made in order to establish the baseline characteristics of the vegetation and soils at the experimental sites, prior to the treatments being applied. Measurements are summarized below:

1. Soil cores were collected at $5 \mathrm{~cm}$ depth at the beginning of the experiment from the plots in each area so that the levels of nitrogen occurring naturally in the soils could be established. Soil samples were air-dried, sieved ( $2 \mathrm{~mm}$ diameter) and milled prior to analysis. Total organic matter was determined with the method of Walkley \& Black (1934), total N with the Kjeldahl method (Bremner 1960), available P by the Bray-Kurtz method (Kalra \& Maynard 1991). Soil pH was determined in $\mathrm{H}_{2} \mathrm{O}$ (ratio 1:2.5).

2. The mean biomass (total dry weight per $\mathrm{m}^{2}$ of Calluna and Erica was measured with the material initially cut in the experimental plots.

3. Five shoots of Calluna and Erica were taken from separate plants in each plot to analyse total $\mathrm{N}$-content.

After treatment, the following measurements were also taken:

1. One soil sample was taken from each plot 1,2 and 3 yr after the treatments. Soil properties determined were: Organic matter and total $\mathrm{N}$ were determined by Walkey \& Black (1934) and Kjeldahl methods (Bremner 1960) respectively. Available P was determined by the BrayKurtz method (Kalra \& Maynard 1991). Soil pH was determined in a ratio 1:2.5 in $\mathrm{H}_{2} \mathrm{O}$.

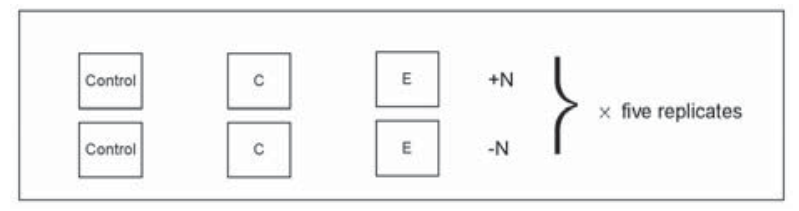

Fig. 1. Experimental layout in each of the three areas. 
2. Five shoots of Calluna and Erica (representing the current year growth) were also taken from each plot to analyse total $\mathrm{N}$-content by the Kjeldahl method, 1,2 and 3 yr after the treatment.

Due to a scarcity in the material collected, some data are missing in the tables and figures.

\section{Data analysis}

Data used to ANOVA were arcsine-square root transformed prior to analysis. Data from soil characteristics and N-content of Calluna and Erica shoots, were analysed by means of factorial analysis of variance (either balanccd ANOVA or, in case of missing values, a linear model. Scheffé $F$-tests were carried out to determine the significance of the differences. All statistical analyses were carried out using the statistical package STASTISTICA' 98 Edition.

A one-way (each treatment and time, repeated measure) ANOVA of soil characteristics and shoot N-content was used to compare the effect of fertilization in successive sets of samples of the same experimental treatment and also to compare the results from the different treatments. The significance of the results was tested with the Tukey test (Tukey 1949).

\section{Results}

\section{Pre-treatment characteristics of soil and vegetation}

The three areas did not differ significantly in their biomass for each species (Table 1). The soil characteristics and $\mathrm{N}$-content of the vegetation differ significantly $(p<0.05)$ between the areas (Table 2). San Isidro has the lowest $\mathrm{pH}$ and highest $\mathrm{P}$-content and contrasts with Vegarada. The organic matter content at Las Señales is twice as high as in the other areas; in fact it has charac-

Table 1. Mean values of biomass $\left(\mathrm{g} \cdot \mathrm{m}^{-2}\right)$, standard errors of the mean and significance (marked by different letters) of the differences between Calluna vulgaris and Erica tetralix.

\begin{tabular}{lccc}
\hline & $\begin{array}{c}\text { Dry weight } \\
\text { Mean }\end{array}$ & $\begin{array}{c}\text { Dry weight } \\
\text { S.E. }\end{array}$ & $\begin{array}{c}\text { Differences } \\
\text { between species }\end{array}$ \\
\hline S. Isidro & & & \\
Calluna & $1857.0 \mathrm{a}$ & 148 & $P<0.001$ \\
Erica & $102.7 \mathrm{~b}$ & 29.9 & \\
Las Señales & & & \\
Calluna & $1295.0 \mathrm{a}$ & 143 & $P<0.001$ \\
Erica & $183.9 \mathrm{~b}$ & 53.8 & \\
Vegarada & & & \\
Calluna & $1439.0 \mathrm{a}$ & 252 & $P<0.001$ \\
Erica & $186.8 \mathrm{~b}$ & 40.1 & \\
\hline
\end{tabular}

Table 2. Characteristics of the soil before the treatments in the three study areas. Standard deviation is shown in brackets. Different letters in the same row indicate significant differences $(p<0.05)$ between areas.

\begin{tabular}{lrrr}
\hline & San Isidro & Las Señales & \multicolumn{1}{c}{ Vegarada } \\
\hline pH & $3.90(0.15)$ a & $3.98(0.28)$ a & $4.35(0.21) \mathrm{b}$ \\
Organic matter (\%) & $21.30(6.83)$ a & $47.21(16.83) \mathrm{b}$ & $26.50(5.36) \mathrm{a}$ \\
Total N (\%) & $0.76(0.36)$ a & $1.16(0.40) \mathrm{b}$ & $0.98(0.26)$ ab \\
Available P (ppm) & $17.63(3.25)$ a & $14.55(5.47) \mathrm{ab}$ & $11.33(3.21) \mathrm{b}$ \\
\hline
\end{tabular}

teristics of a peatland (Martínez-Cortizas et al. 2000). It also has the highest total $\mathrm{N}$-value.

Total N-content for Calluna vulgaris was generally higher than for Erica tetralix (Table 3). Within each species differences the three areas were not significant.

\section{Effects of nitrogen fertilization}

Changes in soil properties

There are no changes in the $\mathrm{pH}$ values during the study period (Fig. 2) and only Vegarada shows a slight decrease in $\mathrm{pH}$ in the first year. There are no significant differences $(p<0.05)$ between treatments in each area. The initial differences in $\mathrm{pH}$ between the areas disappeared after three years (Table 4).

The available P-content tends to decrease through time regardless of the treatment carried out (Fig. 2). The most evident losses in $\mathrm{P}$ occur in San Isidro, particularly during the first year $(p<0.05)$. A gradual decrease occurred in the other two areas. No statistically significant differences $(p<0.05)$ were detected between treatments. Statistically significant differences $(p<0.05)$ were detected between Vegarada and the other areas at the end of the study among the fertilized plots (Table 4).

Organic matter tends to increase through time in the three study areas (Fig. 3). This is a continued, gradual increase at San Isidro and Vegarada. There are significant differences $(p<0.05)$ between treatments (fertilized vs non-fertilized). No statistically significant differences $(p<0.05)$ in organic matter content were detected between treatments. At the end of the study the differences between the study areas remain (Table 4).

At Vegarada and San Isidro the nitrogen content decreased slightly when compared with the original situation and the rest of the samples (Fig. 3), but these

Table 3. Total nitrogen content (\%) in Calluna vulgaris and Erica tetralix before treatments. Different letters in the same row indicate significant differences $(p<0.05)$ between areas.

\begin{tabular}{lccc}
\hline & San Isidro & Las Señales & Vegarada \\
\hline Calluna vulgaris & $0.88(0.21) \mathrm{a}$ & $0.86(0.11) \mathrm{a}$ & $0.88(0.13) \mathrm{a}$ \\
Erica tetralix & $0.69(0.14) \mathrm{a}$ & $0.84(0.15) \mathrm{a}$ & $0.72(0.34) \mathrm{a}$ \\
\hline
\end{tabular}


Table 4. Physical and chemical characteristics of the soil three years after the treatments, fertilized $(\mathrm{N})$ and non-fertilized (non). Different letters in the same row indicate significant differences $(p<0.05)$ between the areas.

\begin{tabular}{lccr}
\hline & San Isidro & Las Señales & Vegarada \\
\hline $\mathrm{pH}($ non) & $4.03(0.15) \mathrm{a}$ & $4.09(0.00) \mathrm{a}$ & $3.97(0.20) \mathrm{a}$ \\
$\mathrm{pH}(\mathrm{N})$ & $3.83(0.19) \mathrm{a}$ & $3.87(0.39) \mathrm{a}$ & $4.07(0.15) \mathrm{a}$ \\
Organic matter (\%) (non) & $32.80(9.28) \mathrm{a}$ & $80.29(0.00) \mathrm{b}$ & $44.58(11.32) \mathrm{a}$ \\
Organic matter (\%) (N) & $39.48(4.93) \mathrm{a}$ & $61.59(1.10) \mathrm{b}$ & $36.38(3.08) \mathrm{a}$ \\
Total N (\%) (non) & $0.60(0.11) \mathrm{a}$ & $1.67(0.00) \mathrm{b}$ & $0.93(0.13) \mathrm{c}$ \\
Total N (\%) (N) & $0.69(0.15) \mathrm{a}$ & $0.78(0.34) \mathrm{a}$ & $0.89(0.11) \mathrm{a}$ \\
Available P (ppm) (non) & $5.56(0.92) \mathrm{a}$ & $1.00(0.00) \mathrm{a}$ & $9.85(4.00) \mathrm{a}$ \\
Available P (ppm) (N) & $4.80(1.09) \mathrm{a}$ & $3.40(1.69) \mathrm{a}$ & $9.75(2.38) \mathrm{b}$ \\
\hline
\end{tabular}

differences are not significant. No statistically significant differences in nitrogen content were detected between treatments (fertilized and non-fertilized). The initial differences between the areas remain after three years in the non-fertilized plots (Table 4). However after fertilization the original differences in the fertilized plots disappear.

\section{Changes in shoot nitrogen content}

Shoots of Calluna and Erica show a significant increase in nitrogen (Fig. 4) after three years treatment ( $p<0.05)$ : initial values of $0.87 \%$ for Calluna, reach values up to $1.43 \%$, and initial values of 0.75 for Erica increase to $1.30 \%$ after three years. The greatest increase in $\mathrm{N}$ was found at Vegarada, i.e. for both species, but Calluna always has higher nitrogen values than Erica.

The clearest increase for Calluna in Vegarada occurs after the first year. In the other two areas $\mathrm{N}$-increase does not occur until the second year. Significant differences $(p<0.05)$ through time were found only in the
Table 5. Nitrogen content in the shoots of Calluna vulgaris and Erica tetralix after $3 \mathrm{yr}$, fertilized (N) and non-fertilized. Different letters in the same row indicate significant differences $(p<0.05)$ between the areas.

\begin{tabular}{lccc}
\hline & San Isidro & Las Señales & Vegarada \\
\hline Calluna vulgaris: & & & \\
Non-fertilized & $1.04(0.09) \mathrm{a}$ & $1.27(0.14) \mathrm{ab}$ & $1.32(0.13) \mathrm{b}$ \\
Fertilized (N) & $1.16(0.05) \mathrm{a}$ & $1.21(0.09) \mathrm{a}$ & $1.43(0.08) \mathrm{b}$ \\
Erica tetralix: & & & \\
Non-fertilized & $1.00(0.03) \mathrm{a}$ & $0.98(0.01) \mathrm{a}$ & $1.30(0.00) \mathrm{b}$ \\
Fertilized $(\mathrm{N})$ & $1.15(0.12) \mathrm{a}$ & $1.04(0.03) \mathrm{a}$ & \\
\hline
\end{tabular}

fertilized plots. N-content in Calluna shoots is higher in the treatments with added N. After three years, the Ncontent in the vegetation at Vegarada was higher $(p<$ $0.05)$, and differences between the areas begin to appear (Table 5).

As to the N-content in Erica tetralix, in Las Señales and San Isidro the clearest increase occurs during the second year. Significant differences $(p<0.05)$ were only found in the fertilized plots. No significant differences $(p<0.05)$ were detected between treatments. In general, the highest contents were found in the plots with added nitrogen.

Shoot nitrogen content in relation to removal of the other species.

The highest nitrogen content in the shoots of both shrub species always occurred in the fertilized plots (Table 6). In all areas, Erica shows an increase in shoot $\mathrm{N}$-content when Calluna is cut. When Erica is cut there is not a clear response in the other species. (Table 6). Independent of the species removed, the new shoots contain more $\mathrm{N}$ than before the treatment.
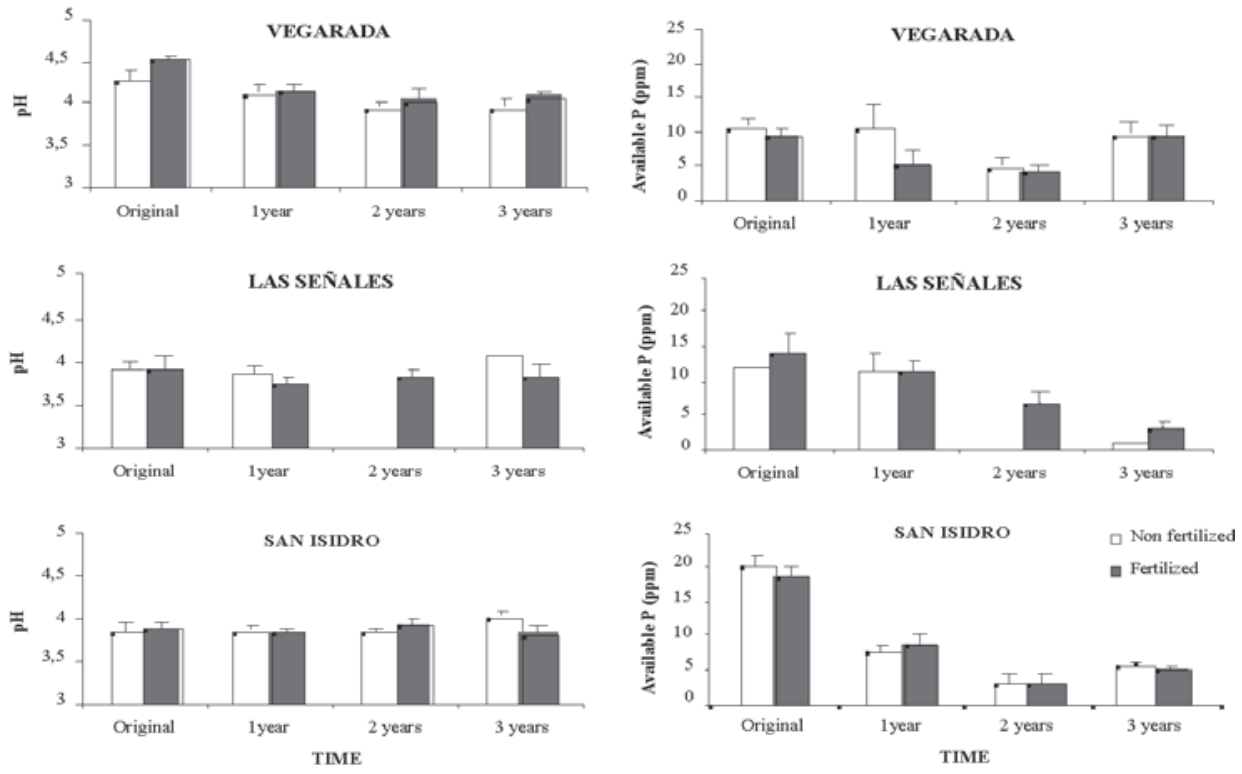

Fig. 2. Mean values and standard error of $\mathrm{pH}$ and available phosphorus in the soil in the control plots throughout the study period (original, 1, 2, and 3 years after treatment) in the three experimental areas. 

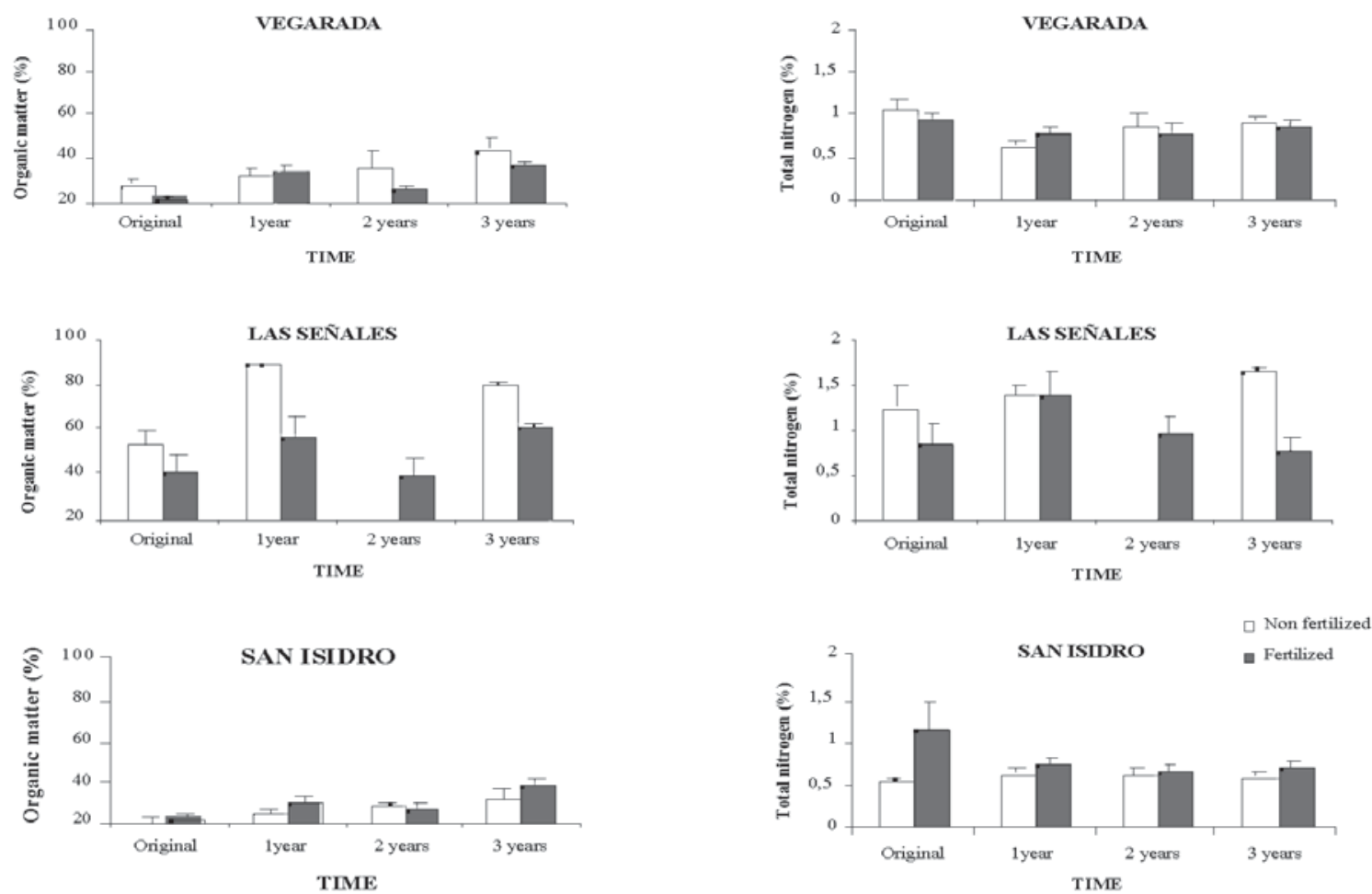

Fig. 3. Mean values and standard error of the organic matter and total nitrogen in the soil in the control plots throughout the study period (original, 1, 2, and 3 years after treatment) in the three experimental areas.
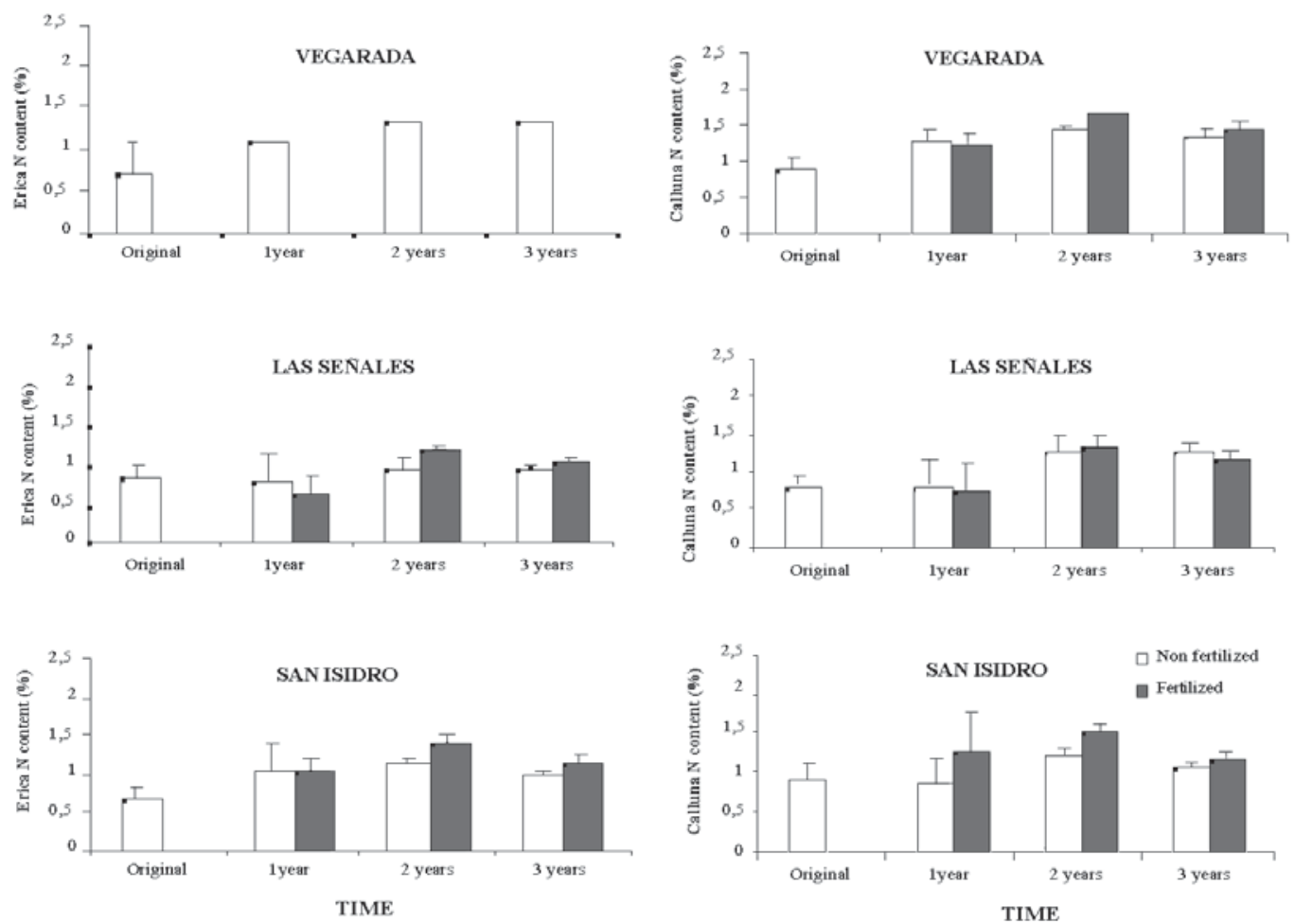

Fig. 4. Mean values and standard error of the total nitrogen content in the shoots of Erica tetralix and Calluna vulgaris in the control plots throughout the study period (original, 1,2, and 3 years after treatment) in the three experimental areas. 


\section{Discussion}

Possible repercussions of nitrogen increase on soil and vegetation characteristics had not been studied previously in Spanish heathlands. Although the floristic composition of the three study areas is similar (Fernández 2002), they have had different land-use histories in terms of grazing intensity. At present two of the three areas have grazing livestock and at the third (San Isidro) sheep grazing pressure was reduced considerably several years ago. Changes in soil characteristics following the experiments have to be interpreted with these differences in grazing history in mind.

The addition of $\mathrm{N}$, as ammonium nitrate, has not resulted in a significant increase in total $\mathrm{N}$ in the soil. Lee \& Caporn (1998) recorded an increase in $\mathrm{N}$ in plant litter as a result of the accumulation of $\mathrm{N}$ in the plant tissues. There may not have been enough time to enrich the soil through the litter of plants richest in nitrogen. Because of the low $\mathrm{pH}$, high $\mathrm{C} / \mathrm{N}$ ratio ( $>30$; Fernández 2002), low temperatures and high rainfall, nitrification will occurs very slowly and the nitric and ammoniac fertilizers are subject to losses by denitrification and lixiviation from the moment they are applied, so they will not remain in the soil. However, the organic matter content increases through time. This tendency has been noted previously by Chapman et al. (1975), Gimingham et al. (1979) and Berendse (1990). In the case of Las Señales the changes in organic content are similar to those occurring in peatlands. This increase is due to slow decomposition probably associated with the effects of pool formation and oligotrophy on microbial activity (Zak \& Grigal 1991; Gorham 1995). This means that a minimum decomposition level is maintained over time.

Heil \& Aerts (1993) stated that $\mathrm{NO}_{2}$ has an acidifying effect in nutrient-poor ecosystems. Our study did not record greater acidification of the soil after the treatments, probably due to the use of ammonium nitrate as fertilizer. Most of the nitrates added or produced by nitrification are absorbed by the plants and there are no excess anions, which require the neutralizing presence of calcium and which are going to be lixiviated later, thus limiting the loss of cations such as calcium (Wild 1992).

For phosphates to be absorbed by plant roots, they must be in the soil solution, although the solution concentration is normally very low and must be renewed frequently. Phosphates generally accumulate on the surface due to their recycling through the vegetation. Our study found a decrease in assimilable $\mathrm{P}$ in the soil in all cases, regardless of the treatment. The highly acid soils are characterized by a very high P-adsorption capacity, which, in turn, implies that concentrations in the soil solution drop if there is no mineralization of P-organic compounds or desorption of the mineral surfaces. Both mineralization and desorption occur very slowly in these areas, so concentrations tend to be very low. Borie (1991) stated that soils with a large capacity for immobilizing $\mathrm{P}$ have managed to accumulate more than 2 tonne/ ha of total $\mathrm{P}$, but the levels of soluble $\mathrm{P}$ can remain at about $15 \mathrm{ppm}$. It would be necessary to establish $\mathrm{C} / \mathrm{P}$ ratios to discover the balance between mineralization and immobilization of plant material.

When the nitrogen content in the shoots of Calluna vulgaris and Erica tetralix is analysed, an increase in nitrogen is detected in all the plots, although it is greater in the fertilized ones. This increase in all cases could be due to continuous atmospheric deposition on the study areas, with a greater increase in shoots resulting from the experimental application of an additional concentration of nitrogen. Using low rates of nitrogen addition means that a large increase cannot be expected in the vegetation, as stated by Uren et al. (1997), who only detected significant differences during the seven months following treatments with $7.7 \mathrm{~kg} \cdot \mathrm{ha}^{-1}$ of nitrogen. No later effects were detected. Similarly, Carrol et al. (1999) did not detect great changes when they applied low doses of $\mathrm{N}\left(4 \mathrm{~g}-\mathrm{N} \cdot \mathrm{m}^{-2} \cdot \mathrm{yr}^{-1}\right)$. However, in studies using 40-200 kg.ha-1 $\mathrm{yr}^{-1}$ of $\mathrm{N}$ (Lee et al. 1992), shoot nitrogen increased from $1.1 \%$ in the control treatment to $1.4 \%$ in the $40 \mathrm{~kg} \cdot \mathrm{ha}^{-1}$ treatment and to $2.3 \%$ in the 200 $\mathrm{kg} \cdot \mathrm{ha}^{-1} \cdot \mathrm{yr}^{-1}$ following two years of application. The results of our study are similar to those obtained with applications of $40 \mathrm{~kg} \cdot \mathrm{ha}^{-1} \cdot \mathrm{yr}^{-1}$ and this is considered a

Table 6. Increase (\%) in the total nitrogen content of Erica tetralix and Calluna vulgaris shoots from the cut plots in relation with the original situation and when the other is removed by cutting. (- = data missing)

\begin{tabular}{|c|c|c|c|c|c|c|c|c|c|c|c|c|c|}
\hline \multirow{3}{*}{ Site } & \multirow{3}{*}{ Treatment } & \multicolumn{6}{|c|}{ Erica tetralix } & \multicolumn{6}{|c|}{ Calluna vulgaris } \\
\hline & & \multicolumn{3}{|c|}{ Non-fertilized } & \multicolumn{3}{|c|}{ Fertilized } & \multicolumn{3}{|c|}{ Non-fertilized } & \multicolumn{3}{|c|}{ Fertilized } \\
\hline & & $1 \mathrm{yr}$ & $2 \mathrm{yr}$ & $3 \mathrm{yr}$ & $1 \mathrm{yr}$ & $2 \mathrm{yr}$ & $3 \mathrm{yr}$ & $1 \mathrm{yr}$ & $2 \mathrm{yr}$ & $3 \mathrm{yr}$ & $1 \mathrm{yr}$ & $2 \mathrm{yr}$ & $3 \mathrm{yr}$ \\
\hline \multirow[t]{2}{*}{ Vegarada } & Cut Calluna & 35.00 & 51.25 & 66.25 & 92.53 & 159.70 & 101.49 & - & 58.13 & 47.67 & 60.91 & 77.01 & 62.06 \\
\hline & Cut Erica & 30.76 & 29.67 & 24.17 & 41.48 & 59.57 & 34.04 & 36.66 & 50.00 & 37.77 & 35.65 & 54.45 & 35.64 \\
\hline \multirow[t]{2}{*}{ Las Señales } & Cut Calluna & - & 13.04 & 10.86 & 2.73 & 47.94 & 63.01 & - & 28.40 & 32.95 & - & 69.41 & 61.76 \\
\hline & Cut Erica & 9.19 & 26.43 & 18.39 & - & 48.05 & 18.18 & - & 49.41 & 42.35 & 17.44 & 84.88 & 51.16 \\
\hline \multirow[t]{2}{*}{ San Isidro } & Cut Calluna & 43.75 & 87.50 & 76.56 & 57.53 & 83.33 & 68.05 & & 43.02 & - & 29.21 & 55.05 & 69.66 \\
\hline & Cut Erica & 23.37 & 59.74 & 53.24 & 85.24 & 98.36 & 104.91 & 7.05 & 48.23 & 34.11 & 8.79 & 53.84 & 30.76 \\
\hline
\end{tabular}


positive response to the fertilization treatment.

Another interesting question is whether the elimination of one of the main species favours an increase in the nitrogen content of the other species. Although a clear tendency cannot be detected after three years, it appears that when Calluna vulgaris is cut, the N-content in Erica tetralix increases, particularly in the fertilization treatments, and the same occurs to Calluna when Erica is cut. In these same areas Fernández (2002) found that Erica increases its cover, especially in fertilized areas, when Calluna is eliminated. It would be interesting to discover which consequences the increase in $\mathrm{N}$ would have on both species and how this would affect them; for this longer-term studies are required.

Heil \& Aerts (1993) stated that the increase in $\mathrm{N}$ in the vegetation increases the frost sensitivity of the species considered, above all Calluna. In the last study year the flowers of Erica tetralix were observed to have been badly damaged by snows and late frosts (pers. obs.). However, as Calluna flowers later it was not affected. It appears that relatively low doses of $\mathrm{N}$ produce a decrease in the frost tolerance of these heathland species.

\section{Conclusions}

The addition of nitrogen produces changes in the nitrogen content of the main woody species of the heathlands studied, namely Calluna vulgaris and Erica tetralix. Greater $\mathrm{N}$-availability produces an increase in the $\mathrm{N}$-content of the shoots of both species and, according to Fernández (2002) for the same areas, it also produces an increase in the growth of the shoots of both species and higher bloom yield. Cutting one of the two species studied favours the accumulation of nitrogen in the other. We cannot be certain that the variations in soil characteristics between study sites are due to the increased nitrogen availability. Probably land use history is the main cause of the differences among the areas. A long term study of the soil and litter is required to discover the effects that these nitrogen depositions could have on the soil and, above all, on the community as a whole.

Acknowledgements. This study was supported by a Diputación Provincial de León project.

\section{References}

Aerts, R. \& Heil, G.W. 1993. Heathlands: Patterns and Processes in a changing environment. Geobotany 20. Kluwer, Dordrecht, NL.

Aerts, R., Berendse, F., De Caluwe, H. \& Schmitz, M. 1990. Competition in heathland along an experimental gradient of nutrient availability. Oikos 57: 310-318.

Berendse, F. 1990. Organic matter accumulation and nitrogen mineralization during secondary succession in heathland ecosystems. J. Ecol. 78: 413-427.

Bobbink, R. \& Heil, G.W. 1993. Atmospheric deposition of sulphur and nitrogen in heathland ecosystems. In: Aerts, R. \& Heil, G.W. (eds.) Heathland: Patterns and processes in a changing environment, pp. 25-50. Kluwer, Dordrecht, NL.

Bobbink, R., Hornug, M. \& Roelofs, J.G.M. 1998. The effects of airbone pollutants on species diversity in natural and semi-natural European vegetation. J. Ecol. 86: 717-738.

Borie, F. 1991. Microbiología del fósforo. Jornadas de Fertilidad de Suelos en Cero Labranza. Sociedad de Conservación de Suelos de Chile e INIA, Concepción, Chile.

Bremner, J.M. 1960. Determination of nitrogen in soil by the Kjeldahl method. J. Agricult. Sci. 55: 11-33.

Calvo, L., Tárrega, R. \& Luis, E. 2002. Regeneration patterns in a Calluna vulgaris heathland in the Cantabrian mountains (NW Spain): effects of burning, cutting and ploughing. Acta Oecol. 23 (2): 81-90.

Carroll, J.A.. Caporn, J.M., Cawley, L., Read, D.J. \& Lee, J.A. 1999. The effect of increased deposition of atmospheric nitrogen on Calluna vulgaris in upland Britain. New Phytol. 141: 423-431.

Chapman, S.B., Hibble, J. \& Rafarel, C.R. 1975. Litter accumulation under Calluna vulgaris on a lowland heath in Britain. J. Ecol. 63: 259-271.

Farrell, L. 1993 Lowland heathland: the extent of habitat change. English Nature Science No. 12, Peterborough, UK.

Fernández, A.J. 2002. Efecto de la concentración de nitrógeno en las comunidades de callunar de alta montaña. Memoria de Licenciatura, Universidad de León.

Gimingham, C.H. 1972. Ecology of heathlands. Chapman and Hall, London, UK.

Gimingham, C.H. Chapman, S.B. \& Webb, N.R. 1979. European heathlands. In: Specht, R.L. (ed.) Ecosystems of the world, 9 A, pp. 365-386. Elsevier, Amsterdam, NL.

Gorham, E. 1995. The biogeochemistry of Northern peatlands and its possible responses to global warming. In: Gorham, E., Woodwell, G.M. \& Mackenzie, F.T. (eds.) Biotic feed backs in the global climatic system, pp.169-186. Oxford University Press, Oxford, UK.

Groves, R.H. 1981. Heathland soils and their fertility status. In: Specht, R.L. (ed.) Ecosystems of the world, 9B. Heathland and related shrublands. Analytical studies, pp. 143150. Elsevier, Amsterdam, NL.

Heil, G.W. \& Aerts, R. 1993. Synthesis: perspectives for heathlands. In: Aerts, R. \& Heil, G.W. (eds.) Heathland: Patterns and Processes in a changing environment, pp. 
201-219. Kluwer, Dordrecht, NL.

Heil, G.W. \& Diemont, W.H. 1983. Raised nutrient levels change heathlands into grasslands. Vegetatio 53: 113-120.

Kalra, Y.P. \& Maynard, D.G. 1991. Methods manual for forest soil and plant analysis. Information Report NORX-319, Minister of Supply and Services Canada.

Lake, S., Bullock, J.M. \& Hartley, S. 2001. Impacts of livestock grazing on lowland heathland in the UK. English Nature Research Report no. 422. Peterborough, UK.

Lee, J.A. \& Caporn, J.M. 1998. Ecological effects of atmospheric reactive nitrogen deposition on semi-natural terrestrial ecosystems. New Phytol. 139: 127-134.

Lee, J.A., Caporn, J.M. \& Read, D.J. 1992. Effects of increasing deposition and acidification on heathlands. In: Schneider, T. (ed.) Acidification research: evaluation and policy applications, pp. 97-106. Elsevier, Amsterdam, NL.

Martínez-Cortizas, A., Pontevedra, X., Novóa, J.C. \& Garcia, E. 2000. Turberas de montaña del noroeste de la Península Ibérica. Edafología 7-1: 1-29.

Nordin, A., Näsholm, T. \& Ericson, L. 1998. Effects of simulated $\mathrm{N}$ deposition on understorey vegetation of a boreal coniferous forest. Funct. Ecol. 12: 691-699.

Pitcair, C.E.R., Fowler, D. \& Grace, J. 1995. Deposition of fixed atmospheric nitrogen and foliar nitrogen content of bryophytes and Calluna vulgaris (L.) Hull. Environm. Poll. 88: 193-205.

Power, S.A., Ashmore, M.R., Cousins D.A. \& Ainsworth, N. 1995. Long-term effects of enhanced nitrogen deposition on a lowland dry heath in Southern Britain. Water Air Soil Poll. 85: 1701-1706.

Power, S.A., Ashmore, M.R. \& Cousins D.A. 1998. Impacts and fate of experimentally enhanced nitrogen deposition on a British lowland heath. Environm Poll. 102: 27-34.
Rivas-Martínez, S., Gandullo, J.M., Allue, J.L., Montero, J.L. \& González, J.L. 1987. Memoria del mapa de series de vegetación de España. ICONA, Madrid, ES.

Rivero Fernández, C., Rabago Juan-Aracil, I., Sousa Carrera, M., Lorente Ibáñez, M. \& Schmid, T. 1996. Cálculo y cartografía de cargas críticas para España. Aplicación del modelo SMB. CIEMAT, Madrid, ES.

Singh, H. 1995. Nitrogen mineralization, microbial biomass and crop yield as affected by wheat residue placement and fertiliser in a semi-arid tropical soil with minimum tillage. J. Appl.Ecol. 32: 588-595.

Tukey, J.W. 1949. Comparing individual means in the analysis of variance. Biometrics 5: 99-114.

Uren, S.C., Ainswoth, N., Power, S.A., Cousins, D.A., Huxedurp, L.M. \& Ashmore, M.R. 1997. Long-term effects of ammonium sulphate on Calluna vulgaris. J. Appl. Ecol. 34: 208-216.

van Jaarsveld, J.A. \& Onderlinden, D. 1990. Trend: an analytical long-term deposition model for multi-scale purposes. Report no. 228603009, National Institute of Public Health and Environmental protection, Bilthoven, NL.

Walkley, A. \& Black, A.I. 1934. An examination of the Degtjoreff method for determinating soil organic matter and a proposed codification of the chromic acid titration method. Soil Science: 37: 29-38.

Watt, A.S. 1955. Bracken versus heather, a study in plant sociology. J. Ecol. 43: 490-506.

Webb, N.R. 1998. The traditional management of European heathlands. J. Appl. Ecol. 35: 987-990.

Wild, A. 1992. Condiciones del suelo y desarrollo de las plantas según Russell. Mundi-Prensa, Madrid, ES.

Zak, D.R. \& Grigal, D.F. 1991. Nitrogen mineralization, nitrification and denitrification in upland and wetland ecosystems. Oecologia 88: 189-196.

Received 18 April 2002; Revision received 13 November 2002; Accepted 14 November 2002. Coordinating Editor: R.H. Marrs. 